\title{
The Implementation of Realistic Mathematics Learning Approach for Function Topic in Class VIII SMP Negeri 1 Sungai Lala
}

\section{ARTICLE'S \\ INFORMATION}

Article history:

Received: Nov-28-2021

Reviewed: Dec-01-2021

Accepted: Dec-28-2021

\begin{tabular}{lr}
\hline Keywords: & Realistic \\
Mathematics & Education, \\
Instructional & Material, \\
Students Achievement
\end{tabular}

Corresponding address:

Sudarmono,

\author{
Sudarmono \\ SMP Negeri 1 Sungai Lala, INDONESIA
}

E-mail: sudarmono.0405@gmail.com

\section{INTRODUCTION}

Learning mathematics is very important because mathematics penetrates the joints of human life. By learning mathematics, students are expected to apply the values contained in mathematics lessons in their daily lives. Values include always thinking logically, critically, consistently, disciplined, democratically, communicatively, and honestly. These values are formed due to the interpretation and application of the characteristics of mathematics itself. The mathematical characteristics stated by [1] have 6 (six) characteristics, namely: 1) having an abstract object of study, 2) relying on the agreement, 3 ) having a deductive mindset, 4) having symbols that are empty of meaning, 5) paying attention to the universe of speech, 6) consistent in the system.

Teaching mathematics should be interesting, fun, and not boring for students. It makes it easier for students to understand facts, properties, rules, concepts, definitions, principles, or theorems of mathematics. To achieve this, an educator (hereinafter referred to as a teacher) and students must be prepared to carry out the teaching and learning process. Readiness in carrying out the teaching and learning process, according to [2], is the overall condition of a person who makes them ready to respond/answer in a certain way to a situation. Thus, learning readiness is the initial condition of a learning activity that makes a person ready to respond or answer students in a certain way to achieve a goal. With the readiness between teachers and students, it is expected that students' willingness and ability to learn mathematics will increase or be very high.

Internationally, the mathematical ability of grade VIII students (in grade 2 of junior high school) in Indonesia is still at a very low level. Indonesia is ranked 44th out of 49 countries with an average 
score of 397, while the average international score is 500 . These results are based on Trends in International Maths and Science Study (TIMSS) tests in 2015.

The low mathematical ability at the international and national levels (nationally, it can be seen in the National Examination scores) must be a serious thought for practitioners of the world of education. According to [3] that the weaknesses of learning mathematics carried out by teachers in schools are; 1) the teacher's low ability to use varied learning methods, 2) the teacher's teaching ability is only limited to answering questions, 3) the teacher does not try to change his teaching method which is already considered correct and effective, and (4) the teacher only uses conventional methods without paying attention to aspects of student thinking. The review must be from various aspects that do not always corner students. Often the causes of student difficulties, according to [4], only come from within the students themselves, so that they become a sharp spotlight, which means as if there are no other causes of difficulties that come from outside the students, for example, the way the lesson is presented or the learning atmosphere is carried out.

According to [5], students' low mathematical problem-solving ability can be overcome, among others, by developing a learning device that can assist students in improving mathematical problemsolving abilities. Teachers need learning tools to develop students' mathematical problem-solving abilities. According to [6], teachers rarely develop learning tools that are in accordance with the characteristics of students. This needs attention from the teacher because of the importance of learning tools prepared by the teacher. The learning device is used as a reference in the learning process because it is still found that it is not in line with the reality encountered.

In addition, the learning process is a very important indicator in seeing the success of learning. This is sometimes still forgotten by the teachers. The teacher only thinks about how the curriculum is achieved how the teaching materials are finished being taught on time. It must be realized that the teacher carries out teaching activities and has to think about how students understand a teaching material and fully master it so that later it becomes a provision for students in dealing with problems in everyday life. This results in that by understanding how teaching materials are delivered, starting from the strategies used, the approaches taken, the methods chosen, and the techniques applied, a teacher will be able to optimize his teaching abilities so that it will have an impact on student success, student enjoyment in learning and students do not feel bored. In addition, teachers must pay attention to learning mathematics so that teaching has clear directions and goals.

According to the Minister of National Education Number 20 of 2006, One of the goals of learning mathematics is to communicate ideas with symbols, tables, diagrams, or other media to clarify the situation or problem. In learning mathematics, mathematical communication both orally and in writing is very important in addition to reasoning, proof, mathematical representation, and mathematical problem solving [7].

The phenomenon that is developing in Indonesian education today is a tendency to carry out constructivist learning. In constructivist understanding, students are expected to construct knowledge that has never been studied by using existing knowledge, meaning that students are not considered empty glasses. Learning that is teacher-centered turns into student-centered. Learning is no longer teacher-centered but student-centered. Students as learning subjects are not objects of learning.

One student-centered mathematics learning (student-centered) and applying mathematics in everyday life is realistic mathematics Learning (RML). RML is very appropriate and beneficial for students because PMR uses contextual problems as a starting point for learning, then students perform horizontal mathematization and vertical mathematization. The problems given are contextual and close to the child's world and everyday life. The teacher poses problems, poses 
questions, and facilitates investigation and dialogue. At the end of the lesson, students are required to conclude the concepts, definitions, principles, rules, or properties they have learned in their way. This shows that students are required to be active in learning.

The realistic Mathematics Approach is an approach to learning mathematics that starts from a real problem and then with a tiered mathematization process, brought to a formal form with a pleasant learning atmosphere $[8,9,10]$. This learning differs from mathematics learning so far, which provides information and uses ready-made mathematics to solve problems [11].

Related to the management of learning, a learning approach is needed, and that approach must be adapted to the learning model that will be used. According to [1], the learning approach is a path, method, or policy taken by the teacher in the process of delivering or presenting a particular topic to make it easier for students to understand it. Choosing the wrong approach will make learning not run according to the planned learning objectives.

According to [12] and [13], learning approaches in mathematics education can be grouped into two components, namely horizontal mathematization and vertical mathematization. Then when viewed from the approach into four kinds of approaches, namely: mechanistic (mechanical), empiricistic (empiristic), structuralistic (structuralistic), and realistic (realistic). The general explanation of the four approaches to learning mathematics based on the intensity of their mathematization is as follows.

1. Mechanistic, in this approach, learning focuses on drills and memorizing formulas and practical solutions 'tricks' rather than attention to the application. Therefore, this approach pays less attention to the horizontal and vertical components of mathematization.

2. Empirical, in this approach, students are offered an environment that can stimulate them to arrive at the development of knowledge (horizontal mathematics). Still, they cannot leap at thought to a more formal level of computation. In other words, there is no tendency to involve a vertical mathematizing component.

3. Structuralistic, in this approach, learning starts from formal calculations. Students are taught a definition/theorem/formula, then given examples of questions, and then given practice questions related to the definitions/theorems/formulas taught. This approach emphasizes more on vertical mathematization than horizontal mathematization.

4. Students build formal mathematics by doing vertical mathematization to solve contextual problems. This approach pays attention to the balance between horizontal and vertical mathematization. Realistically, in learning with this approach, students are given contextual problems starting with problems that match the informal knowledge that students already have.

Realistic Mathematics Education (RME) is a learning approach developing in Indonesia, especially mathematics. The development of RME is based on the ideas of Freudenthal in 1905-1990. In its original place, namely the Netherlands, this mathematical approach is known as Realistic Mathematics Education (RME). In Indonesia, it is defined as Realistic Mathematics Education. Operationally Education is changed to Learning. Henceforth in this study, RME is defined as Realistic Mathematics Learning (RML).

Learning mathematics will be more meaningful if the learning is associated with the real environment of students in students' daily lives. With these conditions, students can immediately see the application of mathematics lessons.

As proposed by [2], Realistic mathematics learning uses reality and the environment understood by students to facilitate the mathematics learning process to achieve the goals of mathematics education better than in the past. In this paper, the word "reality" is real or concrete 
things that students can observe or understand through imagining. What is meant by "environment" is where students are in the school, family, and community environment that students can understand. Educate. Freudenthal says that mathematics must be related to reality, and mathematics is a human activity [14]. This means that mathematics must be close to children and relevant to children's everyday situations.

RML is based on Freudenthal's 1973 argument that mathematics should not be presented to students in the form of a ready-made product [14]. Still, students must learn to rediscover these mathematical concepts. They form mathematical concepts and procedures through realistic and contextual problem solving [15].

Realistic mathematics learning uses contextual problems in learning mathematics. It should be noted that something contextual in a student's environment in one area is not necessarily contextual for students in another area. For example, the internet is contextual for students in big cities, such as Surabaya, Jakarta, Pekanbaru, Medan, but is not necessarily contextual for students in remote areas or remote areas. Therefore, learning mathematics with a realistic approach must be adapted to the circumstances of each area.

Realistic mathematics learning, which is a process of developing ideas and concepts starting from the real world, which is called the conceptual mathematization process, is described as follows:

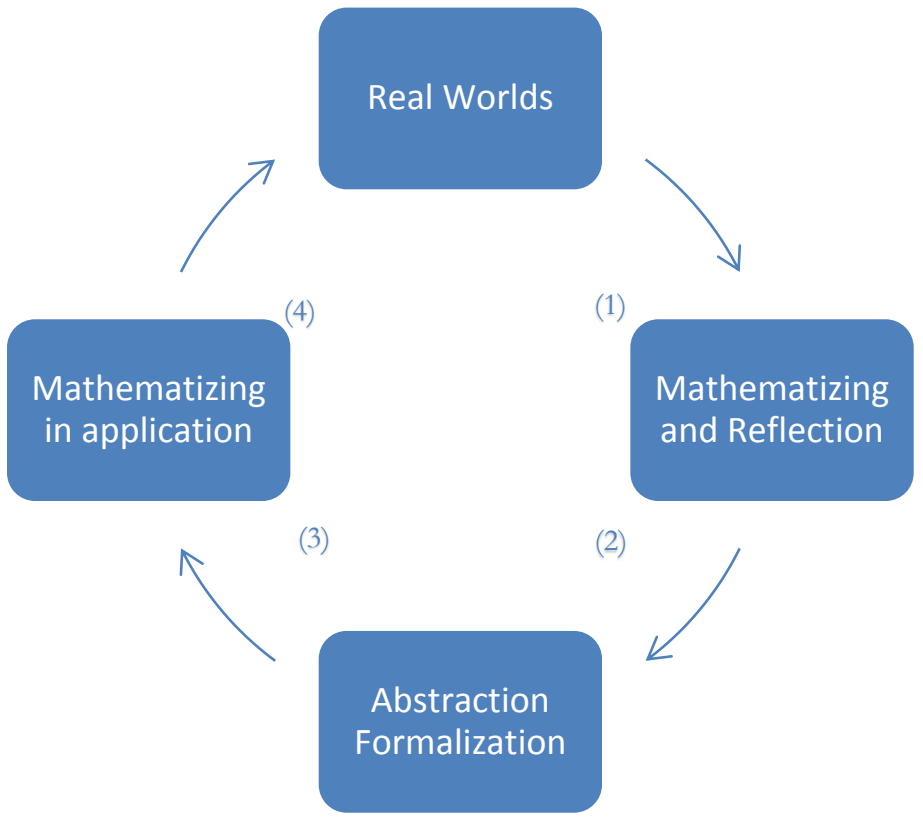

Figure 1. Conceptual Mathematization [13]

Figure 1 shows that (1) the process of learning mathematics takes place from real situations, intuitively students first have mathematical concepts through real-world situations. In this case, students carry out horizontal mathematization activities; namely, they organize, reflect, formulate problems, and identify aspects of the problem mathematically to find the rules or relations, (2) with interactions between students, teachers, and between students and students. Students with a social environment, students are expected to be able to use vertical mathematization by formalizing and abstracting mathematical concepts to give birth to mathematical concepts in students, (3) after mathematical concepts are formed, students are expected to be able to apply them in different problems, and situations and (4) after the concept is applied to different problems, real problems may arise again or be returned to real problems. 
The description above shows that what is meant by realistic mathematics learning (RML) is an approach to learning mathematics that uses contextual problems as a starting point in the mathematics learning process. Students are asked to organize and identify the mathematical aspects contained in the contextual problem. Students are given full freedom to describe, interpret and solve these contextual problems in their way, based on experience or prior knowledge they already have. Then with or without the teacher's help, students are expected to construct facts, definitions, concepts, and principles from contextual problems given by the teacher at the beginning of learning. According to [14], there are three main principles (key principles) in RML, namely: (a) guided reinvention and progressive mathematizing, (b) didactical phenomenology, dan (c) self-developed models. These three principles can be briefly explained as follows.

The first principle is based on reinvention; students can experience the same process as when mathematics was discovered. The history of mathematics can be used as inspiration in designing subject matter. In addition, the principle of reinvention can also be developed based on informal settlement procedures. In this case, the informal strategy can be understood to anticipate formal settlement procedures. For this purpose, it is necessary to formulate contextual problems that can make various completion procedures that indicate learning routes through the process of progressive mathematization.

The researcher's second principle is that this discovery principle refers to the constructivist view, which states that knowledge cannot be transferred or taught through notification from the teacher to students. Still, the students themselves must construct (build) that knowledge by themselves through active learning activities. This principle implies that in studying mathematical facts, definitions, concepts, and principles, students start from problems that come from real situations or problems that can be imagined as real problems. Contextual problems are very important to introduce mathematical topics to students. Determining a contextual problem in RML is based on: (1) to reveal the various applications of a topic that must be anticipated in learning and (2) to consider whether or not the contextual problem is used as points for a progressive mathematization process. This is done by considering the suitability of the contextual problems presented with (1) the mathematics topics being taught and (2) facts, definitions, concepts, and principles of mathematics that students in learning will rediscover.

The third principle is the development of the model itself. In this principle, the models built serve as a bridge between students' informal and formal mathematical knowledge. In solving contextual problems, students are given the freedom to build their mathematical models related to the contextual problems being solved. Consequently, it is possible to appear various models built by students due to that freedom. These various models may initially be similar to the contextual problem. These models are expected to change and lead to formal mathematics.

As the operationalization of the three main principles of RML above, according to [14], RML has five characteristics, namely: (a) the use of context (using contextual problems), (b) the use models, bridging by vertical instruments (using various models), (c) students contribution (using student contributions), (d) interactivity (interactivity), and (e) intertwining (integrated with other topics).

By referring to the principles and characteristics of RML, the steps in the mathematics learning process with the RML approach are as follows.

Step 1: Understanding contextual issues

The teacher gives contextual problems and asks students to understand the problems. Suppose there are certain parts that some students have not understood, students who understand that part is asked to explain them to other students who do not understand. If students who do not understand are still 
dissatisfied, the teacher will explain further by giving limited instructions. If necessary, the teacher can provide a classical explanation.

Instructions, in this case, are in the form of questions that lead students to understand the problem, such as: what is known from the problem? What was asked?

This step is in accordance with the first realistic mathematics learning characteristics, namely using contextual problems (the use of context), which is appointed as a starting point in learning.

Step 2: Solving the contextual problem

Students describe contextual problems, interpret the mathematical aspects of the problem in question, and think of problem-solving strategies. Students individually solve contextual problems in their way. Different ways of solving and answering problems are preferred. Using student workingsheets, students work on questions with different difficulty levels. The teacher observes, motivates, and provides limited guidance so that students can find solutions to these problems in their way. While the characteristics of realistic mathematics learning that are appropriate are the second characteristics, namely using models (use models, bridging by vertical instruments).

Step 3: Comparing and discussing answers

The teacher forms groups and asks the groups to work together to discuss solving the problems that have been solved individually (negotiating, comparing, and discussing). Students are trained to issue ideas related to student interaction in the learning process to optimize learning.

After the discussion is done, the teacher appoints group representatives to write down each solution idea and the reason for the answer. Then, as a facilitator and moderator, the teacher directs students to discuss, guiding students to conclude the topics being taught. This step is in accordance with the third and fourth characteristics of realistic mathematics learning, namely the use of student contributions and interaction (interactivity) between one student and another.

\section{Step 4: Concluding}

From the results of class discussions, the teacher directs students to conclude a formula for a concept/principle from the topic being studied. The characteristic of RML that appears in this step is the interaction (interactivity) between students and teachers.

The functions taught to class VIII SMP students with Competency Standards for algebra units are understanding and performing algebraic operations, functions, line equations, and systems of equations and problem-solving. Basic Competencies for function topics consist of:

1. State the form of the function with the following indicators.

a. Explain in words and daily state problems related to function

b. Declare a function related to everyday events

c. Draw a graph of a function in Cartesian coordinates

2. Calculate the value of the function with the following indicators.

a. Calculating the value of a function

b. Compiling a function table

c. Calculates the value of the function change if the variable changes

Given the limitations of the researcher, the topic used in this study is only basic competency number 1 . The outline of the material used in this study can be seen in the following figure. 


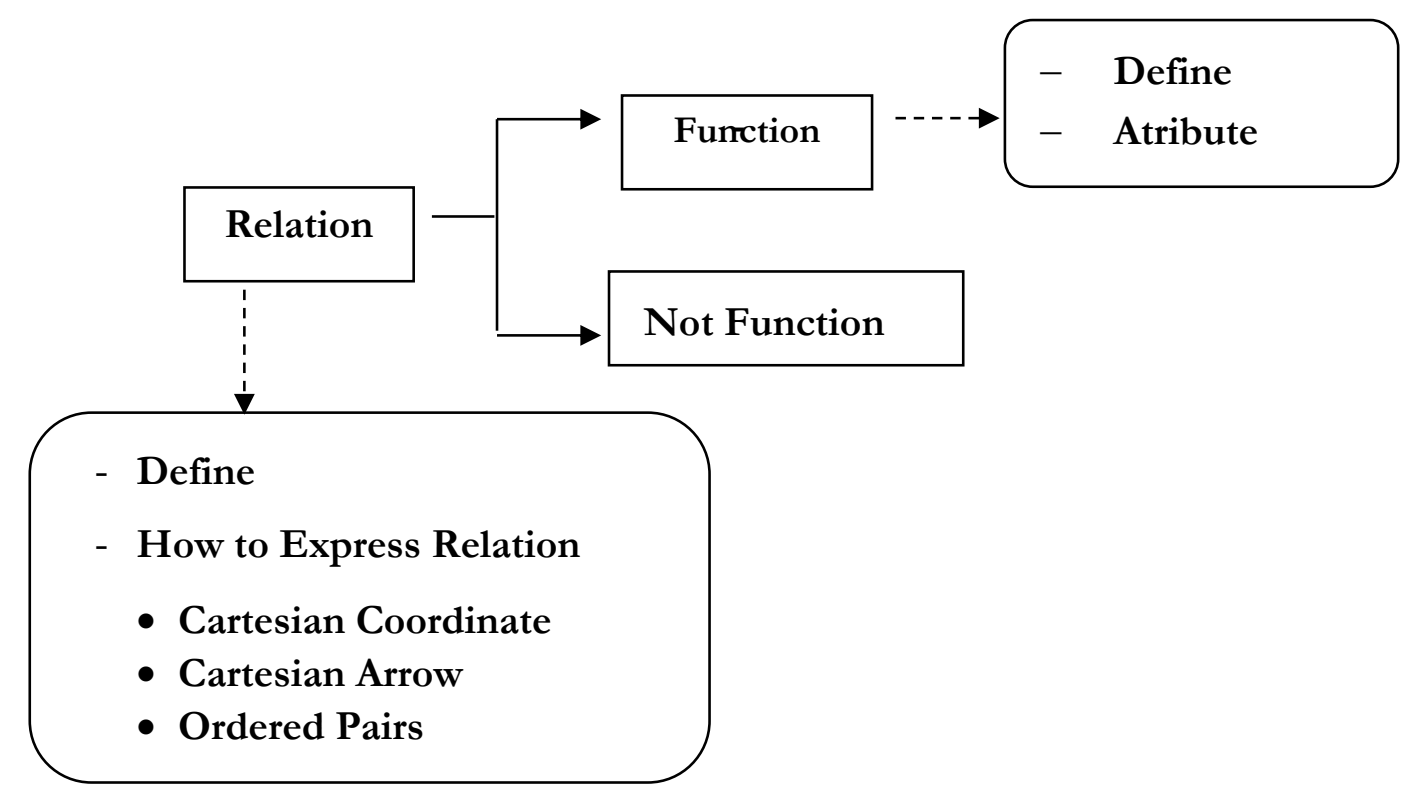

Information:

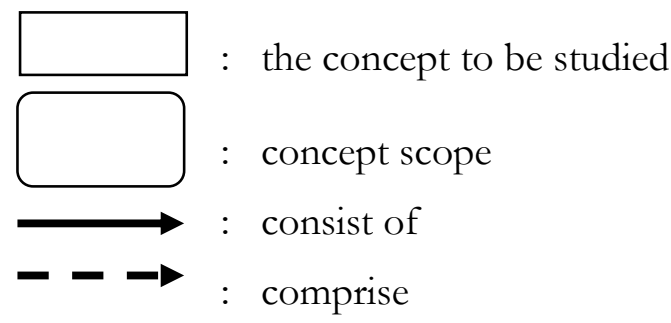

Mathematics learning oriented to PMR is new learning, especially in Indragiri Hulu Regency, Riau Province, so learning tools that can support its implementation in the classroom do not yet exist. Therefore, this research was preceded by developing learning tools for the topic of functions by applying a realistic mathematics learning approach in class VIII of SMPN 1 Sungai Lala. Then the researcher continued to look at the learning outcomes of students who were taught using realistic mathematics learning compared to the learning outcomes of students who were taught using conventional learning for the topic of functions in class VIII of SMPN 1 Sungai Lala.

\section{METHODS}

This research is classified as quasi-experimental research, which begins with development research [16]. The development research in question is research conducted to produce learning tools consisting of lesson plans (RP), teacher manuals (BPG), student books (BS), student activity sheets (LKS), and learning outcomes tests (THB). The development of the device refers to the 4-D model (four-D model) proposed by [17]. This was done to answer how the development and results of developing a good realistic mathematics learning tool for the topic of function in class VIII of SMPN 1 Sungai Lala.

After the learning tools were developed, experimental research was carried out. Learning tools are said to be good/valid if the learning tools after being validated and tested meet the requirements, 1) the teacher's ability to manage learning is at least good, 2) student activities in learning are effective, 3) student responses to learning tools are positive, and (4) test results. The study had a minimum of moderate validity and reliability, and a sensitivity index of more than or equal to $0.3(\mathrm{~S}>0.3)$. It is said to be experimental research because it is marked by the existence of treatments designed 
intentionally to change a condition, namely applying realistic mathematics learning by using learning tools from the results of development research.

To see the effectiveness of realistic mathematics learning on the topic of functions in class VIII of SMPN 1 Sungai Lala, the researcher investigated the description of several things related to realistic mathematics learning, namely: the ability of teachers to manage learning, student activities, classical learning completeness and student responses to learning.

Realistic mathematics learning is effective if at least 3 of the four aspects below are met with the condition that one must be fulfilled. The four aspects are (1) complete classical learning outcomes, (2) teacher's ability to manage learning at least good, (3) student activity, effective (4) student response to positive learning.

To see the difference between student learning outcomes using realistic mathematics learning (PMR) and student learning outcomes using conventional learning, the researchers investigated the differences in student learning outcomes taking realistic mathematics learning and student learning outcomes taking conventional learning.

The research procedure consists of three stages: the preparation stage, the implementation stage, and the data analysis stage.

1. Preparation stage

The activities carried out at this stage are as follows:

a. Developing learning tools.

b. Analyzing the test results of learning devices to revise these devices.

2. Implementation stage

The activities carried out at this stage are as follows:

a. Giving a pretest to the experimental class and control class.

b. Implement realistic mathematics learning for the experimental class and conventional mathematics learning for the control class.

c. Observing student activities and the teacher's ability to manage learning are carried out by one observer each.

d. Providing post-test for the experimental class and control class.

e. Providing student response questionnaires to experimental class students.

3. Data analysis stage

The activity is to analyze the data obtained from the implementation stage.

The development model used to develop learning tools in this study is a modification of the model [16] known as the 4-D model. This model was chosen because it is systematic and suitable for developing learning tools, but the researchers modified the 4-D model in this study. This was done because the 4-D model was designed for learning for exceptional students, while the subjects of this study were ordinary/normal students. The modification of the 4-D model learning device development in this study is presented in the diagram in Figure-2. The results of the development of learning tools can be described as being categorized as good or valid because the requirements for good learning tools are met.

The results of experimental research using learning tools developed for the function topic in class VIII of SMPN 1 Sungai Lala are effective because the requirements for the effectiveness of learning are met. For the difference in learning outcomes, it can be concluded that students who are subject to realistic mathematics learning for the topic of functions are better than the learning outcomes of students who are subject to conventional mathematics learning for the topic of functions. 


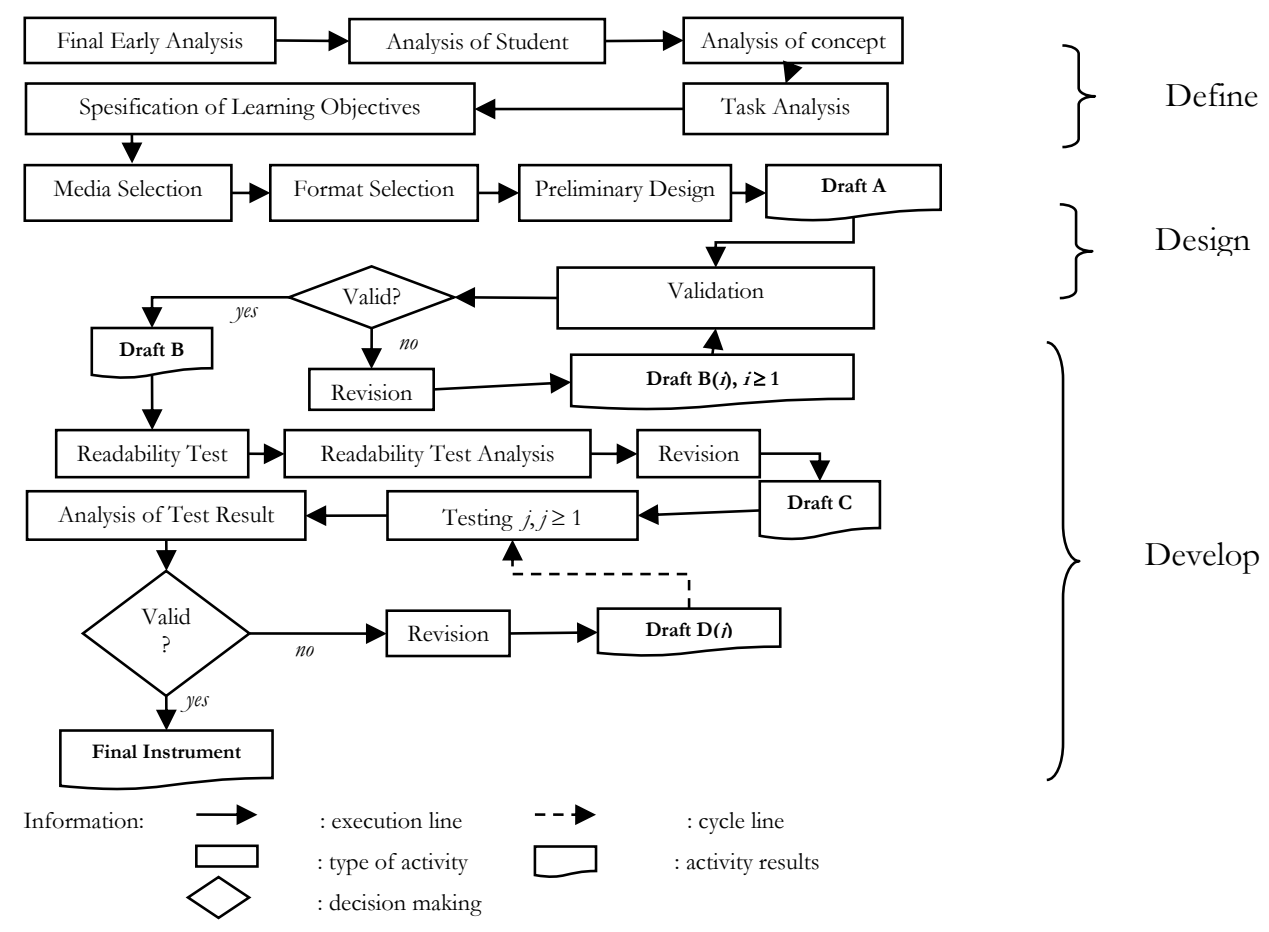

Figure 2. Modification of the Learning Device Development Model from the 4 - D model

\section{RESULTS AND DISCUSSION}

In the test of the device, when viewed from every aspect, the teacher's ability is still in the "not good" category (score 2). This is seen in terms of:

1. Directing students to find answers and answer questions by providing limited assistance.

2. The ability to direct students to find their own and draw conclusions about concepts/principles/definitions/theorems/formulas/mathematical procedures.

This "not good" assessment was found at the first meeting. In this meeting the teacher still provides assistance that crosses the line such as giving answers to students. According to the researcher, this is understandable because the teacher is still adjusting to the learning. This is possible because the teacher is less patient in guiding students to find their concepts to be constructed. To avoid this from happening again, the researcher gave directions to partner teachers.

For student activities, in the device test at the first meeting, there was a percentage of student activity outside the criteria, namely paying attention to/listening to the teacher's/friend's explanation. According to the researcher, this is because students are also adjusting to the learning carried out. The teacher also teaches that they are still much influenced by conventional learning so that student activities still listen a lot to the teacher's explanation. The difference is not far or not significant, so the researcher did not revise the device.

The results of the learning outcomes test analysis consisting of 13 items have valid, sensitive, and reliable criteria. Because of the results of field trials, the learning tools did not experience significant changes, the researchers concluded that the learning tools developed were in a good category.

The results of observations on the ability of teachers to manage to learn were analyzed that the average ability of teachers to manage learning in four meetings reached a minimum category of good. It is based on the criteria of the teacher's ability to manage learning, which is located in the interval 
$3.50 \leq$ TKG $<4.50$ means good and lies in the interval $4.50 \leq \mathrm{TKG}<5.00$ means very good. Because the teacher's ability to manage to learn lies in good and very good criteria, it is concluded that learning is effective when viewed in terms of the teacher's ability to manage to learn.

The observations of student activities in learning every time they meet for four face-to-face meetings are expressed as percentages. The results were analyzed that student activities are in the interval of effectiveness limit criteria in general. From the analysis, it was concluded that learning was effective when viewed from student activities.

In the control class, observations were made but not in detail as in the experimental class because the activities in the two classes were not the same. In general, learning activities are dominated by teachers. The teacher explains the concept interspersed with questions and answers, gives examples of concepts, and provides exercises. Meanwhile, the students' activities were only listening to the description of the concept and answering the questions posed by the teacher, noting the description of the concept, completing the practice questions. The interaction in the discussion was not optimal, and the teacher dominated the conclusion.

The questionnaire results on student responses to the implementation of learning can be analyzed. From 5 aspects, three aspects (60\%) were responded positively by more than $75 \%$ of students, and two aspects (40\%) were responded negatively by less than $75 \%$ of students. This means that if viewed from the student's response to the implementation of learning, this learning is ineffective.

These two aspects arise because the learning atmosphere and how teachers teach are similar to what they have experienced. From the researcher's interview with the teacher, it turns out that the teacher has taught mathematics in groups, but the learning process is different from the method in this study. The teacher believes that the learning environment and teaching in this research are new.

The mastery of student learning, both individually and classically, can be analyzed that the mastery of individual learning outcomes achieved by students in the experimental class $(88.4 \%)$ is higher than that achieved by students in the control class $(11.6 \%)$. This means that if viewed from the completeness of student learning outcomes individually and classically, it is concluded that individual and classical learning outcomes are complete. From the overall descriptive analysis results, it can be concluded that realistic mathematics learning is effective. This is because the requirements for the effectiveness of learning are met.

Inferential statistical analysis was used to test the hypotheses proposed in the study. From ANAKOVA obtained a linear regression model for the experimental class and control class, $\mathrm{Y}_{\mathrm{E}}$ $=10,92+0,83 \mathrm{X}_{\mathrm{E}}$ dan $\mathrm{Y}_{\mathrm{K}}=8,12+0,86 \mathrm{X}_{\mathrm{K}}$. From the two regression models, it can be seen that the regression line constant for the experimental class is greater than the constant. The regression line for the control class is 10,92 , and 8,12. This shows a significant difference. Geometrically the regression line for the experimental class above the regression line for the control class means that the learning outcomes of students who are subjected to realistic mathematics learning for the topic of functions are better than the learning outcomes of students who are subjected to conventional mathematics learning for the topic of functions.

\section{CONCLUSIONS AND SUGGESTIONS}

The results obtained are: (1) the development of realistic mathematics learning tools using 4-D models (four D Models), which have been modified as necessary, resulting in good realistic mathematics learning tools, in accordance with the criteria set by the researcher, for the topic of functions. The learning tools consist of lesson plans (LP), teacher manuals, student books, student 
activity sheets, and learning outcomes tests, (2) realistic mathematics learning for function topics in class VIII of SMPN 1 Sungai Lala, is effective, (3) student learning outcomes using realistic mathematics learning for function topics are better than student learning outcomes using conventional mathematics learning for functions topics.

The researcher gives several suggestions: (1) for the school to reduce the number of students in one class so that later the teacher can provide more optimal guidance. This is based on the fact that in this study, several students should have received guidance but did not receive guidance; (2) for the teachers, teachers are expected to use this learning device to teach function topics. And this device is expected as a guide for teachers in making learning tools for other topics. For teachers, it is also expected that realistic mathematics learning will be a variation in learning; (3) for other researchers, if you want to develop learning tools using realistic mathematics learning (RML), it is recommended to pay attention to aspects of student responses. This is based on the results of this study which states that learning is not effective in terms of student responses.

\section{REFERENCE}

[1] R. Soedjadi, Kiat Pendidikan Matematika di Indonesia; Konstatasi Keadaan Masa Kini Menuju Harapan Masa Depan. Jakarta: Dirjen Dikti Depdiknas, 2000.

[2] Slameto, Belajar dan faktor-faktor yang Mempengarubinya. Jakarta: PT Rineka Cipta, 2013.

[3] Suyono, "Penjajakan Profil Kebutuhan Profesional Guru Sekolah Dasar," 1996.

[4] R. Soedjadi, "Pemanfaatan Realitas dan Lingkungan dalam Pembelajaran Matematika," in Seminar Nasional Realistic Mathematics Education (RME), 2001.

[5] F. C. G. Silalahi, K. Kartini, and N. M. Hutapea, "Pengembangan Perangkat Pembelajaran Matematika Berbasis Model Problem Based Learning untuk Memfasilitasi Kemampuan Pemecahan Masalah Matematis Peserta Didik Kelas VIII SMP," J. Cendekia J. Pendidik. Mat., vol. 5, no. 1, pp. 113-124, 2021.

[6] G. D. S. Rahayu and D. Firmansyah, "PENGEMBANGAN PEMBELAJARAN INOVATIF BERBASIS PENDAMPINGAN BAGI GURU SEKOLAH DASAR (Program Pengabdian di Desa Cipeundeuy Kecamatan Cipeundeuy Kabupaten Bandung Barat)," J. Pengabdi. Kpd. Masy. (Abdimas) IKIP Siliwangi, vol. 1, no. 1, pp. 17-25, 2018.

[7] Yovita, Bambang, and Halini, "Pengaruh Problem Based Learning Terhadap Kemampuan Komunikasi Matematis Siswa Pada Materi Himpunan Kelas VII," J. Pendidik. dan Pembelajaran Khatulistiwa, vol. 2, no. 10, pp. 1-10, 2013.

[8] Sulastri, Marwan, and Duskri, "Kemampuan representasi matematis siswa SMP melalui pendekatan pendidikan matematika realistik Persamaan Linear Satu Variabel ( PLSV ), Pertidaksamaan Linear Satu," Beta J. Tadris Mat., vol. 10, no. 1, pp. 51-69, 2017.

[9] D. Wahyuni, "Pengembangan Multimedia Pembelajaran Matematika Dengan Pendekatan Matematika Realistik," AKSIOMA J. Progr. Stud. Pendidik. Mat., vol. 8, no. 1, pp. 32-40, 2019.

[10] Y. Yusmaniar, "Pendekatan Matematika Realistik Untuk Meningkatkan Hasil Belajar Siswa Kelas I Pada Operasi Hitung," JPPI Jurnal Penelit. Pendidik. Indones., vol. 3, no. 1, pp. 51-58, 2017.

[11] N. S. Widyastuti and P. Pujiastuti, "Pengaruh Pendidikan Matematika Realistik Indonesia (Pmri) Terhadap Pemahaman Konsep dan Berpikir Logis Siswa," J. Prima Edukasia, vol. 2, no. 2, pp. 183-193, 2014.

[12] A. Treffers, "Realistic Mathematics Education in the Netherlands 1980-1990," in Streeflands (ed). "Realistic Mathematics Education In Primary School.," Utrecht: Freudenthal Institute, 1991.

[13] J. De Lange, Mathematics, Insight and Meaning. Utrecht: The Nederlands, 1987.

[14] K. Gravemeijer, "Developing Realistic Mathematics Education," 1994.

[15] D. Armanto, "Teaching Multiplication and Division Realiscally in Indonesian Primary Schools: 
A Prototype of Local Instructional Theory," Utrecht University, 2002.

[16] S. Arikunto, Prosedur Penelitian Suatu Pendekatan Praktik. Jakarta: Rineka Cipta, 2016.

[17] S. Thiagarajan, D. S. Semmel, and M. I. Semmel, Instructional Development for Training Teacher of Exceptional Children. Bloomington: Indiana University, 1974.

\section{BIOGRAPHY}

\section{Sudarmono}

Sudarmono studied at: 1. SDN KP Besar Kota 004 Tahun 1985. 2) SMPN I Rengat in 1988, 3) SMAN 1 Rengat in 1991, 4) S1 Matchematic Education UNRI in 1997 dan 5) S2 Mathematic Education UNESA in 2006. He works as the headmaster of SMPN 1 Sungai Lala. Adress: Jl. Basuki Mulya Desa Perkebunan Sei Lala Kecamatan Sungai Lala Kabupaten Indragiri Hulu Provinsi Riau. 